Géographie physique et Quaternaire

\title{
On Sampling and Sorting of Pebbles and Cobbles on Shores, a Comment on "Shape Development of Trondhjemite Pebbles and Cobbles on Shores in the Southwestern Finnish Archipelago", by Mauri Pyökäri (1980)
}

\section{Matti Seppälä}

Volume 36, numéro 3, 1982

URI : https://id.erudit.org/iderudit/032486ar

DOI : https://doi.org/10.7202/032486ar

Aller au sommaire du numéro

Éditeur(s)

Les Presses de l'Université de Montréal

ISSN

0705-7199 (imprimé)

1492-143X (numérique)

Découvrir la revue

Citer ce document

Seppälä, M. (1982). On Sampling and Sorting of Pebbles and Cobbles on Shores, a Comment on "Shape Development of Trondhjemite Pebbles and Cobbles on Shores in the Southwestern Finnish Archipelago", by Mauri Pyökäri (1980).

Géographie physique et Quaternaire, 36(3), 331-334.

https://doi.org/10.7202/032486ar 


\section{Commentaires}

\section{ON SAMPLING AND SORTING OF PEBBLES AND COBBLES ON SHORES, A COMMENT ON "SHAPE DEVELOPMENT OF TRONDHJEMITE PEBBLES AND COBBLES ON SHORES IN THE SOUTHWESTERN FINNISH ARCHI- PELAGO”, BY MAURI PYÖKÄRI (1980)}

Matti SEPPÄLÄ, Department of Geography, University of Helsinki, Hallituskatu 11-13, SF-00100 Helsinki 10, Finland.

Pebble shape development under different geomorphic processes is an interesting topic to study. Glacial, glaciofluvial and coastal processes differ so much from one another that it is most obvious that the abrasion forms should be different. However, it is difficult to determine the exact process involved in a specific change if the stones have been subjected to all these processes. In this journal (Géogr. phys. Quat., 1980, vol. XXXIV, no. 3, p. 335-350), Dr. Mauri Pyökäri has published a study on pebbles and cobbles on shores in SW Finland. This study gives me some reasons to raise comments.

When studying a sedimentological topic with quantitative and statistical methods, the most critical phase is correct sampling. Pyökäri has first divided the trondhjemite pebble and cobble populations in each locality into four groups according to their size: 16-32 $\mathrm{mm}, 32-64 \mathrm{~mm}, 64-128 \mathrm{~mm}$, and 128-256 mm. At each site 20 pebbles or cobbles from each size class were collected and measured. Subsequently, different indices were calculated according to the parameters measured. Whilst it is quite valid to compare measures for different materials for a given size class, comparisons of mean roundness, mean sphericity and mean oblate-prolate indices of "all sizes" (Tables I-III and Figs. 2-4) may not represent the true nature of esker, till or beach materials because we do not know the complete size distributions of these materials. The sampling technique used has homogenized the material. Further, it is stated that the pebbles and cobbles appear in equal sizes and quantities in each sediment. However, it is well known that in every esker there are finer and coarser layers (Fig. 1) and that the internal grain size distributions vary greatly from place to place. Further, tills can have layered structures characterized by markedly different grain-size distributions. In such cases, bulk sampling should first be done and the material should then be split into sub-size groups. For example, 80 or 100 stones could have been taken ramdomly from each locality without selection. Statistical evaluations do not give any significance to the values of "all sizes". They are values which represent some artificial populations of fabrics which the researcher crested by deficiencies in the sampling procedure.

The other comment concerns the comparison of till material with moraine shore materials. Most of the moraine shores are located at about $25 \mathrm{~km}$ from the till sampling points. Since we know how variable the composition of till may be, it is more or less risky and worthless to compare samples which are taken so far from one another. Till is not only composed of "fresh" stones removed from bedrock but it may also contain all types of pre- and inter-glacial material. The author does not explain why he did not sample the till from the same locations as the shore material by digging through the shore deposits down to the original glacial till underneath. This would have given more comparable material for the study. Pyökäri has compared populations of pebbles and cobbles from inside an esker and from inside a moraine with populations of pebbles and cobbles from beach surfaces. We do not know how surface pebbles on a beach relate to the beach pebble population as a whole. Waves disturb a beach to an unknown depth so that the pebbles selected, sorted and abraded by the waves are much more numerous than those found on the surface. The problem of the effect of ice-push on this layer is in this case an open question. It is also well known that the larger, flatter pebbles tend to concentrate on a transport surface. This means that the samples cannot be strictly compared.

When studying sediments and reaching conclusions according to their characteristics, we should think how the different processes are working in this special case. Nearly all investigators agree that, when one pebble or cobble is studied during abrading processes, an increase in sphericity goes hand in hand with an increase in roundness and this is especially true with homogeneous material like trondhjemite where no breakage due to cleavage planes occurs. Pyökäri shows several examples where roundness increases but sphericity decreases. This can only be true when there is longshore drift or burial in beach deposits. Flat, 
disk-like pebbles are more easely transported than more spherical ones, and at the same time roundness increases slightly due to wear during transport. But then the author compares different things. The presumed original population is changed due to longshore drift. Roundness increases due to wear, but the original population of pebble sphericities is split-up into a series of different populations. The most spherical pebbles remain closest to the source while the less spherical ones move to more remote places. Although the average sphericity of the original population will have increased due to wear as well, one finds new sub-populations of varying sphericity on different stretches of the beach. Depending on the location of the sampling site, results obtained will vary along the shore especially if sampling is done along a profile transverse to the water-line. For all these reasons, Pyökäri's contention that differences in pebble characteristics can be ascribed simply or even predominantly to abrasion rather than to selection during transport cannot be sustained. Inadequate sampling has meant that the influences of selection during transport on beach surfaces (as opposed to within beach deposits) cannot be separated from the effects of abrasion during transport.

It is obvious that the stones subjected to many processes have to wear on their edges. The strongest wearing process in the study site in SW Finland has been without doubt glaciofluvial transportation which led to esker formation. It is questionable whether the low wave energy in the practically tideless Finnish archipelago has been strong enough to modify cobbles and pebbles when the effective time and fetch have both been short. In such low-energy environments sorting is mainly in a beach-parallel direction (HUMBERT, 1968), but Pyökäri does not discuss longshore differences. Roundness is a rather good parameter to judge the amount of abrasion, whereas sphericity and oblate/ prolate index tells more about the selection. Pyökäri does not compare the differences between his subenvironments, i.e. between the samples from $50 \mathrm{~cm}$

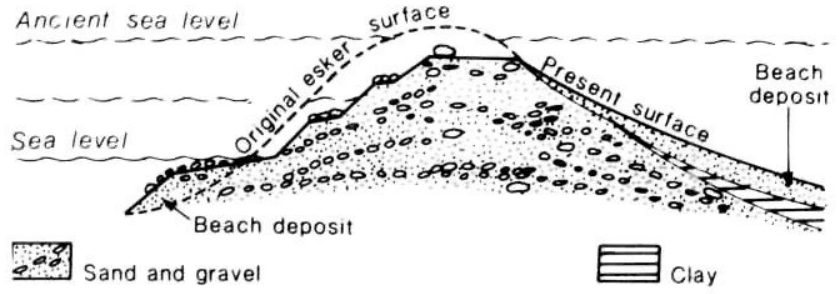

FIGURE 1. Simplified scheme of cross-section of an esker running parallel to the beach in Southern Finland, a region with rapid land uplift.

Schéma simplifié de la coupe d'un esker parallèle à la plage, au sud de la Finlande, une région où le relèvement isostatique est rapide.

below low water level and other shore zones. This would show the effects of beach-normal sorting as well as any differences in wear. Because of land uplift, waves have eroded several layers of eskers (Fig. 1) and till deposits, and could have sorted by transport the most suitable stones in form and size depositing them in particular shore localities. Grain size composition of sampled material should tell something of this process but this had not been demonstrated. Of course, random sampling in the esker material is not enough to indicate grain size distribution of the whole section from which the material on the shore has been sorted by waves.

The questions raised here should be construed as having been made in a constructive manner and should help researchers in more careful sampling of material on beaches.

\section{REFERENCES}

HUMBERT, F.H. (1968): Selection and wear of pebbles on gravel beaches, Geologisch Institut, Groningen, Netherlands, Publication No. 190, 144 p.

PYOKÄRI, M. (1980): Shape development of trondhjemite pebbles and cobbles on shores in the southwestern Finnish archipelago, Géogr. phys. Quat., Vol. 34, p. 335-350. 